\title{
POR UMA HISTÓRIA A PARTIR DOS CONCEITOS: ÁFRICA, CULTURA NEGRA E LEI 10.639/2003. REFLEXÕES PARA DESCONSTRUIR CERTEZAS
}

\author{
Ivaldo Marciano de França Lima ${ }^{1}$
}

\begin{abstract}
Resumo: Este artigo objetiva discutir alguns dos muitos conceitos utilizados pelos historiadores e estudiosos em geral para entender as práticas e os costumes dos negros e negras do Brasil. O presente trabalho pretende refletir em torno de conceitos utilizados de forma acrítica, por especialistas de diferentes áreas das ciências humanas, para desvendar ou traduzir temas relacionados com as religiões de terreiro, bem como com as manifestações culturais de um modo geral. $\mathrm{O}$ artigo também apresenta algumas reflexões em torno da Lei 10.639 , que foi gestada sob a perspectiva do paradigma panafricanista, de que todos os negros e negras do mundo são africanos ou descendentes destes. Um dos muitos desdobramentos deste paradigma consiste em estabelecer liames entre a história da África e dos negros e negras do Brasil, como se ambas consistissem em continuidades. Tais questões são tratadas como construções sócio-históricas, e como tal, passíveis da análise crítica.

Palavras-Chave: Religiões; Cultura; África; Lei 10.639.
\end{abstract}

Resumen: Este artículo tiene por objetivo la discusión de algunos de los muchos conceptos empleados por los historiadores y estudiosos en general para la comprehensión de las practicas y de las costumbres de los negros y las negras de Brasil. Se articula la reflexión acerca de conceptos empleados de manera acrítica por científicos de distintas áreas de las ciencias humanísticas, con el objetivo de comprender o traducir temáticas relacionadas con las religiones de "terrero", así como con las manifestaciones culturales en general. También presenta algunos aportes en torno a la Ley 10.639, que ha sido desarrollada bajo la perspctiva del paradigma panafricanista, según el princípio de que todos los negros y las negras del mundo son africanos o sus descendientes. Una de las muchas consecuencias de este paradigma resulta en establecer conexiones entre la historia de África y de los negros y las negras de Brasil, como si ambas las historias fueran continuidades. Tales cuestiones son tratadas como construcciones sociohistoricas y como tal sujetas a análisis críticos.

Palavras-Ilave: Religiones; Cultura; África; Ley 10.639.

1 Professor Adjunto de História da África, junto ao Departamento de História, da Universidade do Estado da Bahia (UNEB), Campus II, Alagoinhas; Colaborador do Programa de Pós-Graduação em Crítica Cultural (Pós-Crítica/UNEB II). Endereço eletrônico: ivaldomar ciano@yahoo.com.br. 


\section{INTRODUÇÃO}

Diante de tantas incertezas trazidas com os ventos da pósmodernidade, parece-me que algumas áreas do conhecimento existentes nas ciências humanas ainda permanecem pautadas em dogmas, difíceis de serem questionados e, por que não dizer, enfrentados. Analisar os conceitos "afro-brasileiro", "afro-descendente", "africanos", de certa forma consagrados, ou mesmo, na quase relação de sinônimos existentes na ideia de que todo negro é, invariavelmente, descendente dos homens e mulheres "trazidos" para o novo mundo sob a forma de escravos, é tocar em feridas ainda não cicatrizadas, e submeter-se a debates que de certa forma ainda são fortemente influenciados pelos movimentos sociais. Nesse mesmo bojo incluo a lei 10639/2003, que é sempre discutida sob a perspectiva da mesma não estar sendo cumprida a contento, ou de que ela se constitui em uma conquista dos negros e negras deste país, e etc. Mas, em nenhum momento identifico discussões a respeito dos seus limites, ou dos contextos e contornos que cercam sua criação e implementação. A análise destes temas é quase sempre envolta sob o signo dos tabus. Trata-se de temas proibidos ao debate ou a reflexão? Ou estamos às voltas com problemas da ordem do inconsciente e de identidades pautadas em questões políticas que impedem a discussão de determinados temas?

Devo insistir que tanto os conceitos, como as leis precisam, quase sempre, serem submetidos a análises que nos tragam certezas de seus significados. Não posso, entretanto, jogar no mesmo fosso as leis e os conceitos. Quanto aos conceitos, estou me referindo às idéias utilizadas para entender determinados fenômenos e realidades. Se são os melhores, ou mais apropriados para traduzirem dadas realidades e fatos colocados diante dos historiadores, cientistas sociais e intelectuais de modo geral. Revolução, religião, raça, classe social não são apenas nomes. Brasileiro, ou africano, nesse sentido, estão muito além de serem simples adjetivos pátrios.

Em relação às leis, devem ser entendidas como regras, normas que permitem viver em sociedade, dirimindo conflitos entre os homens e muIheres, que possuem diferenças de classes, gêneros, religiões, orientações sexuais, descendências, raças, pontos de vista, concepções de mundo, e etc. As leis devem impor, no dizer de alguns cientistas políticos, as regras que estabeleçam o convívio com as diferenças, sejam elas quais sejam.

A questão que me pergunto é: será que o uso dos conceitos acima colocados (afro-brasileiro, afro-descendente, sincretismo, africano) nos permite entender os fenômenos relacionados às religiões, práticas, costu- 
mes culturais ou a história do continente africano? Pode-se pensar que a história do candomblé baiano, ou do maracatu pernambucano, se constitui em história do continente africano? Aliás, é possível pensar que há uma relação intrínseca entre a cor da pele e a descendência biológica, que nos permite afirmar serem todos os negros e negras deste país descendentes dos africanos que para aqui foram trazidos como escravos? Ou esta não é uma relação que deva ser pensada no campo da biologia e da genética, mas tão somente no campo da cultura? E a propósito, todos os negros e negras deste país se vêem como descendentes de africanos? E se por acaso a resposta seja positiva, não seria tal relação uma construção histórica? Para uma melhor compreensão dos conceitos, remeterei o leitor e a leitora às palavras de Koselleck, para melhor entendimento a respeito da questão que trago neste artigo:

[...] Foi preciso aprofundar a especialização da análise de conceitos a fim de evitar que a especificidade de seu método fosse identificada, de maneira precipitada, com questões de caráter social e histórico, relacionadas a conteúdos extralingüísticos. Certamente é possível desenvolver uma história da língua concebida como história social. No entanto, a história dos conceitos é delimitada de modo mais rigoroso. A especialização metodológica da história dos conceitos, os quais se expressam por palavras, requer um fundamento que possa diferenciar as expressões "conceito" e "palavra". Ainda que o "significado" (conceito) e "coisa" seja usado em suas mais diferentes variantes, no campo das ciências históricas existe, do ponto de vista pragmático, uma diferença sutil: a terminologia social e política da língua que se examina conhece uma série de expressões que, por causa da exegese da crítica de fontes, podem ser caracterizadas como conceitos. Todo conceito se prende a uma palavra, mas nem toda palavra é um conceito social e político ${ }^{2}$.

A discussão acima, encetada por Reinhart Koselleck, sinaliza para que os historiadores estabeleçam em seus trabalhos um maior cuidado com o uso dos conceitos, sobretudo quando estes são tomados sem uma reflexão apurada. Nem sempre a palavra pode ser tomada como um conceito. Creio que este conselho pode ser estendido aos estudiosos e estudiosas de maneira geral. E nada melhor do que tomar apoio nos trabalhos de Koselleck, célebre estudioso dos conceitos, para mostrar que minhas reflexões não são desprovidas de sentido. Esta discussão, sem dúvida, se aplica ao presente caso que venho discutindo desde o início destas linhas, sobretudo quando me refiro aos conceitos que estão ligados aos textos sobre práticas e costumes da história dos negros e negras em nosso país, historicamente

2 KOSELLECK, Reinhart. Futuro passado. Rio de Janeiro: Contraponto, 2006, p. 108. 
marginalizados e socialmente excluídos, em grande parte devido ao racismo que ainda possui grande força na sociedade brasileira ${ }^{3}$.

Um racismo diferente daquele existente nos EUA, ou do que foi implementado pelo regime do apartheid na África do Sul, ou na antiga Rodésia (atual Zimbabwe), é verdade, mas um racismo tão cruel e virulento como estes citados ${ }^{4}$. Um racismo que baliza os números da exclusão sóciohistórico-econômica a que são submetidos os negros e negras em nosso país, e ao mesmo tempo, um racismo que ainda permanece mascarado, mas dotado de grande força em nosso imaginário, mesmo nas nossas formas de pensar, até entre aqueles e aquelas que se definem como antiracistas $^{5}$. Mas, é este racismo que não pode e não deve ser visto como fruto

3 Sobre as questões relacionadas com o racismo e a discriminação racial, fundamentais para entender com maior profundidade algumas das questões que trago neste artigo, ver: HASENBALG, Carlos. Discriminação e desigualdades raciais no Brasil. Belo Horizonte: Ed. UFMG; Rio de Janeiro, IUPERJ, 2005; GUIMARÃES, Antonio Sérgio Alfredo. Racismo e anti-racismo no Brasil. 2. ed. São Paulo: Ed. 34, 2005; GUIMARÃES, Antonio Sérgio Alfredo. Classes, raças e democracia. São Paulo: Ed. 34, 2002; GUIMARÃES, Antonio Sérgio Alfredo. Preconceito e discriminação - queixas de ofensas e tratamento desigual dos negros no Brasil. 2. ed. São Paulo: Ed. 34, 2004; GUIMARÃES, Antonio Sérgio Alfredo; HUNTLEY, Lynn. Tirando a máscara. Ensaios sobre o racismo no Brasil. São Paulo: Paz e Terra, 2000; TURRA, Cleusa; VENTURI, Gustavo. (Org.). Racismo cordial - a mais completa análise sobre preconceito de cor no Brasil. São Paulo: Ática, 1998; COMAS, Juan; LITTLE, Kenneth I; SHAPIRO, Harry; LEIRIS, Michel; LÉVI-STRAUSS, Claude. Raça e ciência. São Paulo: Perspectiva, 1970; WIEVIORKA, Michel. O racismo, uma introdução. São Paulo: Perspectiva, 2007. Sobre o conceito de raça, ver também: GUIMARÃES, Antonio Sérgio Alfredo. Preconceito racial. Modos, temas e tempos. São Paulo: Ed. Cortez, 2008; HASENBALG. Carlos. Relações raciais no contexto nacional e internacional. In: HASENBALG, Carlos A.; MUNANGA, Kabenguele; SCHWARCZ, Lília Moritz. (Org.). Racismo: perspectivas para um estudo contextualizado da sociedade brasileira. Niterói: EDUFF, 1998.

Sobre a natureza do racismo brasileiro, ver: NOGUEIRA, Oracy. Preconceito de marca. As relações raciais em Itapetininga. São Paulo: EDUSP, 1998. Sobre as relações raciais na antiga Rodésia, atual Zimbabwe, ver: FRY, Peter. A persistência da raça. Ensaios antropológicos sobre o Brasil e a África austral. Rio de Janeiro: Civ. Brasileira, 2005.

No que tange ao que denomino de racismo nas formas de pensar, refiro-me aos contornos diversos que este fenômeno toma em nossa sociedade, sobretudo quando em determinados momentos este se apresenta com roupagens sutis e finas. Uma forma clássica deste racismo sutil é o que está presente nos "anti-racistas", e diz respeito às "quedas" momentâneas de alguns destes para as essencializações. Como se houvessem temas de pesquisa proibidos para brancos ou para negros, ou, como se a cor da pele representasse a determinação das formas de pensar. Tal perspectiva, a meu ver, se constitui nas camisas de força a que alguns intelectuais estão submetidos, tanto negros como brancos. Recordo agora de um diálogo a respeito da cor de minha pele, e do que eu estava fazendo na sala de aula como professor de história da África. Tal questionamento me deixou em 128 Número temático: Literatura, cultura e memória negra. A Cor das Letras - UEFS, n. 12, 2011 
de um passado distante, como uma simples herança do nosso passado escravista. Acima de tudo, refiro-me a um racismo que se retroalimenta no quotidiano, no tempo presente, o que não impede de possuir relações com o passado, desde que este não seja visto como a causa primeira de todos os males.

\section{REPENSANDO OS CONCEITOS - LIMITES E INCOERÊNCIAS}

Em relação ao subtítulo acima, refiro-me a questão do uso indiscriminado dos conceitos "afro-brasileiro" e "afro-descendente" para nomear as práticas e os costumes construídos pelos negros e negras em nosso país, sem que em nenhum momento nos questionemos a respeito do uso da palavra "negro" e "negra", socialmente carregados de pesadas cargas negativas. Aludindo ao já célebre trabalho de Munanga, Rediscutindo a mestiçagem, em relação aos negros brasileiros, nosso país foi palco de um etnocídio discursivo, tanto em relação ao uso das palavras "negro" e "negra", bem como no que diz respeito ao auto-reconhecimento e identificação racial $^{6}$. Não preciso discorrer muito, entretanto, para mostrar o quanto é difícil ser negro no Brasil, tanto nas questões de ordem estética, como nos diversos aspectos da vida social'.

boa situação para devolver a pergunta que me foi feita: "e por acaso todo professor de história da África deve ser negro"? E depois disso indaguei se a única possibilidade do negro ou da negra estar na universidade é exatamente lecionando ou pesquisando sobre temas "negros"? Meu interlocutor ficou em situação difícil, pois quase foi obrigado a dizer que música clássica, história da Europa e outros temas "não-negros" se constituem em áreas proibidas, ou dispensáveis para negros. Esta forma de pensar e de enxergar o mundo, eivada de essencializações, a meu ver, impede que mesmo alguns "anti-racistas" percebam o quanto o racismo está presente em suas mentes.

6 MUNANGA, Kabengelê. Rediscutindo a mestiçagem no Brasil. Belo Horizonte: Autêntica, 2004.

7 Sobre esta questão, ver: SOUZA, Neusa Santos. Tornar-se negro. Rio de Janeiro: Graal, 1990; GOMES, Nilma Lino. Sem perder a raiz. Corpo e cabelo como símbolos da identidade negra. Belo Horizonte: Autêntica, 2006. Uma boa discussão a respeito dos salões de beleza étnicos, fruto da positivação da negritude, pode ser visto em: SANTOS, Jocélio Teles. O negro no espelho: imagens e discursos nos salões de beleza étnicos. Estudos AfroAsiáticos, n. 38, p. 49-65, 2000. Não posso deixar de lembrar que uma grande quantidade de meninas negras perde suas vidas, ou os seus cabelos, devido à imposição explícita da estética dos cabelos lisos, normatizado socialmente como "cabelos de brancos", ou "cabelos bons". Em minhas andanças por Alagoinhas conheci uma pequena garota, de apenas oito anos de idade, que se ressentia dos seus cabelos "duros" e "ruins". Esta criança me fez lembrar minha amada filha Mayara Lima. Seus cabelos de menina negra são acei- 
É nesse sentido que afirmo que o uso de categorias conceituais como afro-brasileiro ou afro-descendente, se por um lado tentam enquadrar uma significativa variedade de cores e tons existentes nas pessoas, decorrentes da mestiçagem existente em nosso país, por outro lado tentam ocultar o fato de que são negros e negras que constroem estas práticas, usos e costumes. Gostaria apenas de enfatizar que para a categoria "negro" não atribuo valor absoluto, havendo grande quantidade de tons de pele, tipos de cabelo, traços físicos e etc. Mas no geral, pelo profundo respeito aos mais diferentes setores do movimento negro brasileiro, entendo o uso da categoria "negro" como forma de nomear as práticas e os costumes em que os homens negros e as mulheres negras foram (ou são!) predominantes no processo de construção. Assim sendo, não vejo sentido em nomear os maracatus pernambucanos, ou os afoxés (baianos e pernambucanos), por exemplo, como parte da "cultura afro-brasileira" ou "afro-descendente". Por que não enquadrá-los como parte da cultura negra?

Uma discussão sobre os conceitos "Afro-descendente" e "afrobrasileiro" é necessária uma vez que expressam visões acerca dos problemas raciais existentes no Brasil, ao longo de uma história complexa na qual os debates em torno da questão racial foram centrais e, por momentos, pensou-se que estes conceitos resolveriam muitas das questões colocadas, eximindo os que as usam de expressar valores e posições políticas. Faz-se necessário estabelecer uma discussão a respeito dos conceitos utilizados pelos cientistas sociais em geral para nomear determinadas práticas e costumes sócio-histórico-culturais.

Para esta questão, ressalto que também não posso deixar de lado outro debate que ganhou força no final do século XIX, e em alguns casos subsidiou políticas efetivas, que é o não reconhecimento dos negros e das negras como cidadãos brasileiros. Os conceitos de "afro-brasileiro" e "afrodescendente" retiram, mesmo que implicitamente, a brasilidade e a cidadania dos homens negros e das mulheres negras em nosso país, quebrando inclusive, com o paradigma da brasilidade indistinta existente na obra de

tos por ela, seguramente devido aos muitos diálogos que tivemos, além das histórias que contei para ela. Mayara Lima é uma prova de que é possível construir uma sociedade meIhor, mais humana e justa, se todos os dias optarmos pelo combate ao racismo, preconceito e todas as formas de intolerância. Esta criança que eu conheci, na comunidade de Miguel Velho, em Alagoinhas, talvez seja uma das muitas usuárias da "chapinha", se não conseguirmos mudar os padrões estéticos de beleza racial existentes em nossa sociedade.

130 Número temático: Literatura, cultura e memória negra. A Cor das Letras - UEFS, n. 12, 2011 
Freyre, sobretudo a que foi expressa na obra Casa Grande e Senzala ${ }^{8}$. Mesmo que na prática alguns sejam mais brasileiros do que outros, mostrando que esta "brasilidade indistinta" só serve para os homens e mulheres de pele branca e cabelos lisos. Os conceitos "afro-brasileiro" e "afrodescendente" se constituem em armadilhas que fazem dos negros e negras deste país verdadeiros estrangeiros, ou, na melhor das hipóteses, cidadãos e cidadãs de segunda classe ${ }^{9}$.

Tomemos como exemplo a música, para não perdemos muito tempo e leitura: se um homem branco estiver produzindo cultura em uma comunidade qualquer, seguramente a maior parte dos intelectuais ao analisarem o fato atribuirá ao mesmo o título de "produtor de cultura popular", ou simplesmente cultura brasileira. Mas, se pensarmos que este mesmo homem é negro, o título será deslocado para "cultura afro-brasileira". A brasilidade indistinta, a que me referi acima, serve apenas para os homens e as mulheres de cor branca, que recebem naturalmente o título e a cidadania brasileira em todos os sentidos. Os negros, estes devem sempre ser entendidos como "afro-brasileiros", ou, em outras palavras, quase brasileiros. Mais uma vez recorrendo a Kabenguele Munanga, em sua consagrada obra já citada, "Rediscutindo a mestiçagem" a palavra "negro", conforme já visto, foi acometida do etnocídio discursivo, possível de ser observado na grande quantidade de nomes que foram inventados ao longo dos anos, nos mais diferentes censos realizados em nosso país, para nomear aqueles e aquelas que não se encaixavam no perfil do homem ou da mulher de cor branca. Moreno escuro, claro ou jambo, pardo, mulato ou moreno quase branco, dentre outros termos, foram utilizados por diferentes pessoas para se afastarem do rótulo "indesejável" de negro.

Para os que se contrapõem a este raciocínio, uma simples pergunta pode ser feita: se para os não-brancos existem mais de uma centena de termos, conforme Munanga, alguém por acaso já ouviu falar ou conheceu alguma pessoa que se defina como "branco transparente", "branco claro" ou "branco escuro"? Não! Branco é branco e ponto final. E além de brancos, brasileiros por completo. Não necessitam de outro adjetivo. São cidadãos plenos tanto na efetividade, como no discurso. Quanto aos negros, estes devem ser vistos como "quase brasileiros", ou, em outras palavras,

8 FREYRE, Gilberto. Casa grande e senzala. São Paulo: Global, 2006.

9 Uma excelente discussão a respeito pode ser vista em: NAXARA, Márcia Regina Capelari. Estrangeiro em sua própria terra. Representações do brasileiro - 1870/1920. São Paulo: Annablume/FAPESP, 2002. 
afro-brasileiros, ou afro-descendentes. Este último conceito, conforme explicação de uma grande amiga, serve para dar conta do grande número de tons de peles existentes em nosso país. Ora, se a palavra "negro" não serve para se referir aos supostos "herdeiros" dos africanos, por que então usar um conceito que naturaliza relações de descendência? E para tornar mais complexa ainda nossa questão, não seria o conceito "afro-descendente" homogeneizador dos diversos tons de peles existentes no continente africano? Estamos admitindo que na África existem tão somente negros?

\section{AFRICANOS E NEGROS: A HOMOGENEIZAÇÃO DOS HOMENS E MULHERES DA ÁFRICA}

Outra questão que desejo abordar nestas linhas, diz respeito à profunda confusão existente em diversos trabalhos a respeito das categorias "negro" e "africano". Não posso deixar de recorrer ao instigante trabalho Na casa de meu pai, de Kwame Appiah, para afirmar que é preciso desfazer esse amálgama existente entre as palavras "negro" e "africano", principalmente por estar tratando de conceitos que se referem a realidades distin$\operatorname{tas}^{10}$. Para Appiah, não é possível tratar os africanos de modo homogêneo, uma vez que neste continente existem realidades díspares, às vezes com maior discrepância do que aquela encontrada na Europa. Ou seja, há diferenças enormes entre um cidadão de Gana e um da Namíbia, assim como entre um achanti e um khoi. É preciso maior cuidado com o uso indiscriminado de conceitos no campo da História, conforme afirmei acima, principalmente quando estamos diante de realidades extremamente complexas e ainda merecedoras de estudos que venham corroborar com novas conclusões. Ao que me parece, a homogeneidade existente nos trabalhos daqueles e daquelas que se referem aos vários povos da África como africanos é fruto deste racismo inconsciente, que perpassa vários trabalhos em diversos sentidos e aspectos. Quando nos referimos aos europeus, dificilmente os tratamos por este termo. Em geral, nos utilizamos dos adjetivos pátrios disponíveis, nomeando-os por portugueses, ingleses, franceses, alemães e etc.

Por africanos entendemos todos e todas oriundos e oriundas do continente africano. khoisans, mandingas, zulus, xhosas, amáricos, nupes, dinkas, somalis... Povos extremamente diferentes entre si tanto no que tange

10 APPIAH, Kwame Anthony. Na casa de meu pai. A África na filosofia da cultura. Rio de Janeiro: Contraponto, 2008.

132 Número temático: Literatura, cultura e memória negra. A Cor das Letras - UEFS, n. 12, 2011 
as suas práticas, como organização sócio-cultural, percepção de mundo, valores, costumes, idéias... Não há nada mais diverso e diferente do que o continente africano. Mas tal diversidade e complexidade, no entanto, não impede que alguns intelectuais façam uso de tal conceito com relativa facilidade: africanos! E neste aspecto uma consideração é por demais significativa, posto que traga consigo questões diretamente relacionadas com a história. Ao atribuirmos o conceito de africano para os povos da África, de modo indiscriminado para todos os momentos e épocas da história, cometemos o anacronismo de achar que as populações deste continente se viam como uma unidade, um todo homogêneo, ou mesmo um corpo solidário.

Não que eu seja contra o uso dos adjetivos pátrios, mas o termo "africano" tem seus usos e sentidos para muito além do "inocente" e "simples" adjetivo pátrio. Pensar nos povos da África de modo homogêneo é aludir, mesmo que de forma implícita, ao que Ki-Zerbo denominou por barragem de mitos, e que $\mathrm{M}^{\prime}$ Bokolo conceitua por mitos científicos ${ }^{11}$. É pensar que os africanos são dotados da passividade histórica, questão cara para os povos do continente africano, e afirmativa clássica dos textos da historiografia produzida pelos ex-administradores coloniais europeus. Ora, se todos os povos da África são africanos, como puderam deixar-se escravizar pelos europeus? E como estes conseguiram invadir e colonizar a quase totalidade dos países africanos? Quando tomamos para a História o que é da paixão, ou dos movimentos sociais, terminamos enveredando por caminhos que nem sempre nos permitem entender realidades complexas ${ }^{12}$.

11 KI-ZERBO, Joseph. História da África negra, v. I. Mem Martins (Portugal): Biblioteca Universitária, 2002; M’BOKOLO, Elikia. África negra. História e civilizações - tomo I (até o século XVIII). Salvador/São Paulo: EDUFBA/Casa das Áfricas, 2009.

12

Eu poderia ter citado outras questões para exemplificar os perigos do uso indiscriminado de categorias e conceitos, mas preferi ficar nestes dois exemplos. No que tange a questão da escravidão, e ao fenômeno conhecido como tráfico Atlântico, diferentes povos foram envolvidos sob as mais diversas situações. A escravidão já era conhecida pelos povos do continente africano antes da chegada dos europeus no século $\mathrm{XV}$, assim como o tráfico Atlântico não se constituiu na base das oposições envolvendo europeus e africanos. Estes últimos participaram de forma ativa do tráfico, seja como agente na captura de escravos, seja como vendedor destes. O romantismo e ingenuidade presente na visão de que os europeus sozinhos escravizaram os africanos é por demais perigosa pelo fato de jogar os povos do continente africano para o fosso da passividade histórica, um mito científico ainda hoje dotado de grande força, segundo Elikia M'Bokolo. No que diz respeito ao período colonial, antecedido pela conferência de Berlim, evidente que a superioridade militar das potências européias foi decisiva para a concretização das invasões, mas isso não nos autoriza a acreditar que houve uma simples oposição entre africanos e europeus. Alguns 
Portanto, afirmar que algo ou alguma coisa é africana é por deveras complexo e difícil. É preciso tomar cuidado com as generalizações, principalmente quando estamos nos referindo a um continente dotado das complexidades típicas da imensa variedade de povos, culturas e línguas. O que é uma típica comida africana? O que vem a ser a religião africana? Ou então, o que se entende por língua africana? No tocante a esta, ressalte-se o fato de que no continente africano existe mais de duas mil línguas, distribuídas por sete famílias lingüísticas, o que faz com que um falante do suaili esteja mais distante de um nativo em xona, do que alguém familiarizado com o português e o espanhol. Enfim, a categoria "africano" não nos ajuda muito a entender parte dos mistérios e enigmas existentes neste continente. Além do que, conforme Lovejoy em seu belo trabalho a respeito de Baquaqua, os homens e mulheres trazidos para as Américas como escravos dispunham de opções diversas para constituírem suas identidades, como o uso de chapéus, possíveis de serem empregados de acordo com as conveniências e necessidades. Escravo de determinada nação, africano, integrante de determinado povo ou grupo étnico, ou simplesmente escravo... ${ }^{13}$.

povos africanos apoiaram determinadas invasões, a partir do estabelecimento de alianças, enquanto outros foram contrários a qualquer tipo de acordo ou cooperação. No dizer de M'Bembe, os povos do continente africano não podem ser vítimas da vitimização histórica a que são impostos, e devem ser vistos sempre como protagonistas de suas próprias histórias. Sobre esta questão, ver: $\mathrm{M}^{\prime} \mathrm{BEMBE}$, Achille. As formas africanas de autoinscrição. Estudos Afro-Asiáticos, n. 1, p. 172-209, 2001. Sobre o tráfico Atlântico, ver: REDIKER, Marcus. O navio negreiro. Uma história humana. São Paulo: Cia. das Letras, 2011; SILVA, Alberto da Costa e. Francisco Félix de Souza, mercador de escravos. Rio de Janeiro: Nova Fronteira/Ed. UERJ, 2004; THORNTON, John. A África e os africanos na formação do mundo atlântico - 1400-1800. Rio de Janeiro: Elsevier, 2004; LOVEJOY, Paul. E. A escravidão na África. Uma história de suas transformações. Rio de Janeiro: Civ. Brasileira, 2002; OGOT, B. A. A história das sociedades africanas de 1500 a 1800: conclusão. In: OGOT, B. A. (Org). História geral da África, v. V - África do século XVI ao XVIII. Brasília: UNESCO/MEC, 2010, p. 1057-1069. Sobre a conferência de Berlim, e as invasões no continente africano após os anos 1880, ver: AJAYI, J. F. Ade (Org). História geral da África, $v$. $\mathrm{VI}$ - África do século XIX à década de 1880. Brasília: UNESCO/MEC, 2010; BOAHEN, Albert Adu. (Org). História geral da África, v. VII - África sob dominação colonial, 18801935. Brasília: UNESCO/MEC, 2010; WESSELING, H. L. Dividir para dominar. A partilha da África 1880-1914. Rio de Janeiro: UFRJ/Revan, 1998; OLIVER, Roland. A experiência africana - da pré-história aos dias atuais. Jorge Zahar, Rio de Janeiro: 1994.

13 LOVEJOY, Paul. Identidade e a miragem da etnicidade. A jornada de Mahommah Gardo Baquaqua para as Américas. Afro-Ásia, n. 27, 2002, p. 9-39.

134 Número temático: Literatura, cultura e memória negra. A Cor das Letras - UEFS, n. 12, 2011 


\section{RELIGIÕES - ALGUMAS QUESTÕES PARA PROBLEMATIZAR O USO DOS CONCEITOS}

A respeito das religiões praticadas nos terreiros, que no geral possuem como um dos seus momentos maiores a possessão e o transe, características centrais da relação entre o humano e o divino/sagrado, os problemas com os conceitos ganham maior complexidade.

No geral, estas religiões praticadas nos terreiros a que me referi são consideradas por grande parte dos militantes dos movimentos sociais negros como de "matriz africana", ou pelos termos "afro-brasileiro" ou "afrodescendente". A historiografia com a qual trabalhei utiliza os três conceitos sem questionar as contribuições culturais diversas das quais esta religiões são tributárias ${ }^{14}$. O que significa ser "afro-descendente" neste contexto? Ser negro? Significa compartilhar uma religião que foi trazida nos porões dos navios negreiros? Como explicar, por exemplo, que a maior parte dos praticantes da jurema sejam negros e negras, mas o corpo doutrinário, as entidades cultuadas, os mitos e pontos ${ }^{15}$ cantados não são de "origem" africanas? ${ }^{16}$

14 Para conferir alguns trabalhos que utilizam os conceitos a que me referi, ver: DANTAS, Beatriz Góis. Vovó Nagô e papai branco usos e abusos da África no Brasil. Rio de Janeiro: Graal, 1988; CAPELLI, Rogério. Saindo da rota. Uma discussão sobre a pureza na religiosidade afro-brasileira. Dissertação (Mestrado em história). Universidade Federal Fluminense, Niterói, 2007; QUEIROZ, Martha Rosa Figueira. Religiões afro-brasileiras no Recife: intelectuais, policiais e repressão. 1999. Dissertação (Mestrado em história) - Programa de Pós-Graduação em História, Universidade Federal de Pernambuco, Recife, 1999. Há quem recuse, de modo tácito, o uso dos conceitos acima citados. Um bom exemplo pode ser visto em: CAMPOS, Zuleica Dantas Pereira. O combate ao catimbó: práticas repressivas as religiões afro-umbandistas nos anos trinta e quarenta. Tese (Doutorado em História). Universidade Federal de Pernambuco, Recife, 2001.

Ponto é o termo usado pela comunidade juremeira para nomear as diversas músicas cantadas durante as sessões de jurema. Sobre os significados de algumas das letras dos pontos existentes na jurema, ver: CARVALHO, José Jorge. A tradição mística afrobrasileira. Série Antropologia. Brasília: UNB, 1998.

A jurema é bastante complexa, mas pode ser definida como uma religião de entidades, a exemplo dos mestres e mestras, caboclos e caboclas, índios e índias, exus e pomba giras. Estas entidades fazem trabalhos mágicos dos mais variados, a exemplo da cura para enfermidades diversas, problemas relacionados a casamentos (tanto para fazê-los como para desfazê-los), empregos, ganhos materiais e limpezas espirituais. É costume afirmar entre aqueles e aquelas que fazem a jurema que sua religião cura, consola e diverte, uma vez que as cerimônias são regadas com muita bebida e comida em meio à festa. Na jurema existem elementos de diferentes matrizes, podendo ser vistas associadas em um complexo coerente, contribuições bantos, iorubanas, ameríndias e européias. 
O que significa, neste contexto, definir uma religião como sendo de "matriz africana"? Este conceito é, a meu ver, uma criação do movimento social que reverbera na academia, provocando perigosos erros de generalizações imprecisas. Estas apontam para a invisibilidade de um sem número de práticas, costumes e heranças que não são, necessariamente, eivadas de uma "cosmovisão africana" (Aliás, é possível afirmar que existe uma cosmovisão africana, mesmo após a leitura da obra já citada de Kwame Appiah?). A jurema, por exemplo, não pode ser tratada como uma religião de matriz africana, posto que suas características indígenas e cristãs saltem aos olhos do primeiro pesquisador que a contempla diante de $\mathrm{si}^{17}$. Aliás, para entender a jurema é fundamental perceber que estamos nos referindo a

17 Sobre a jurema, ver: PINTO, Clélia Moreira. Saravá Jurema Sagrada: as várias faces de um culto mediúnico. Dissertação (Mestrado em Antropologia). Recife, UFPE, 1995, especialmente p. 11-12; 15-22; LIMA, Ivaldo Marciano de França. Uma religião que cura, consola e diverte - as redes de sociabilidade da Jurema sagrada. Cadernos de Estudos Sociais, v. 20, n. 2, jul.-dez. 2004; LUZURIAGA, José Martin Desmaras. Jurema e cura - ensaio etnográfico sobre uma forma de jurema nas periferias do Recife. Dissertação (Mestrado em Antropologia). Recife, UFPE, 2001; BRANDÃO, Maria do Carmo; RIOS, Luis Felipe. O catimbó-jurema do Recife. In: PRANDI, Reginaldo. (Org.). Encantaria brasileira. Rio de Janeiro: Pallas, 2001, p. 160-181; BRANDÃO, Maria do Carmo Tinôco; NASCIMENTO, Luis Felipe Rios do. Nuevos modelos religiosos afro-recifenses y las políticas de identidad e integración. In: Antropologia en Castilla y León e IberoAmérica, V. Emigración e integración cultural. Salamanca: Ediciones Universidad Salamanca, Instituto de Investigaciones Antropológicas de Castilla y León, s/d, p. 327-338; MOTTA, Roberto Mauro Cortez. Jurema. In: MAIOR, Mário Souto; VALENTE, Waldemar. (Org.). Antologia pernambucana de folclore. Recife: Massangana, 1988, p. 267-268; MOTTA, Roberto. Catimbós, xangôs e umbandas na região do Recife. In: MOTTA, Roberto. (Coord.). Os afros-brasileiros. Anais do III congresso afro-brasileiro. Recife: Massangana, 1985, p. 109-123; MOTTA, Roberto. Religiões afro-recifenses: ensaios de classificação. Revista Antropológicas, ano II, v. 2, série Religiões populares. Recife: Ed. UFPE, 1997, p. 11-34; SALLES, Sandro Guimarães de. À sombra da jurema encantada: mestres juremeiros na umbanda de Alhandra. Recife: Editora da UFPE, 2010; SALLES, Sandro Guimarães de. À sombra da jurema: a tradição dos mestres juremeiros na umbanda de Alhandra. Anthropólogicas, ano 8, v. 15, p. 99-122, 2004; ASSUNÇÃO, Luiz. O reino dos mestres - a tradição da jurema na umbanda nordestina. Rio de Janeiro: Pallas, 2006. Sobre o catimbó, ver: CASCUDO, Luis da Câmara. Meleagro - pesquisa do catimbó e notas da magia branca no Brasil. 2. ed. Rio de Janeiro: Agir, 1978; CASCUDO, Luis da Câmara. Notas sobre o catimbó. In: Idem. Novos Estudos AfroBrasileiros. Recife: Ed. Massangana, 1988. Edição Fac-similar de Novos Estudos AfroBrasileiros, Trabalhos apresentados ao I Congresso Afro-brasileiro do Recife, segundo tomo, Rio de Janeiro: Civ. Brasileira, 1937; VANDEZANDE, René. Catimbó. Pesquisa exploratória sobre uma forma nordestina de religião mediúnica. Dissertação (Mestrado em Sociologia). Recife, UFPE, 1975.

136 Número temático: Literatura, cultura e memória negra. A Cor das Letras - UEFS, n. 12, 2011 
uma religião de composição, no qual as partes constituem um todo coerente e organizado, dotado de sentidos. Infelizmente esta religião sofre com os problemas de outro conceito largamente utilizado, que é o de sincretismo, como se as partes de uma religião fossem justapostas, ou mesmo que estejamos tratando de agregações desprovidas de $\operatorname{sentidos}^{18}$.

As umbandas, então, constituem o ponto maior desta questão, posto que referir-se às mesmas como "matriz africana" é esquecer que sua constituição e seus primórdios estão eivados de elementos bem distantes do que se convencionou denominar por "africano", a exemplo da idéia de evolução, elemento bastante presente nas mais variadas umbandas que conheci pelo país afora ${ }^{19}$.

Creio que utilizar o conceito de "matriz africana" para as religiões de divindades ${ }^{20}$ e de entidades como um todo é reforçar a distorção criada por

18 Uma indicação a respeito do sincretismo enquanto conceito pode ser visto em: FERRETI, Sérgio Figueiredo. Repensando o sincretismo. São Paulo/São Luís: Edusp/Fapema, 1995. O autor em questão defende o uso do conceito, uma vez que acredita em sua atualidade para explicar os fenômenos das trocas existentes nas religiões. Pessoalmente não concordo com as posições do autor em questão, mas me parece ser o que melhor define o sincretismo enquanto conceito.

19

Sobre a umbanda, ver: ORTIZ, Renato. A morte branca do feiticeiro negro: umbanda $e$ sociedade brasileira. 2. ed. São Paulo: Brasiliense, 1991; NEGRÃO, Lísias. A umbanda como expressão de religiosidade popular. Religião e sociedade. Rio de Janeiro: Civ. Brasileira, 1979; NEGRÃO, Lísias. Umbanda: entre a cruz e a encruzilhada. Tempo Social, São Paulo, v. 5, 1994; NEGRÃO, Lísias. Umbanda: entre a cruz e a encruzilhada: formação do campo umbandista em São Paulo. São Paulo: EDUSP, 1996; MOTTA, Roberto. Catimbós, xangôs e umbandas na região do Recife. In: MOTTA, Roberto. (Coord.). Os afrosbrasileiros. Op. cit.; MEYER, Marlyse. Maria Padilha e toda a sua quadrilha - de amante de um rei de Castela a Pomba-Gira de umbanda. São Paulo: Duas Cidades, 1993; BIRMAN, Patrícia. O que é umbanda? São Paulo: Brasiliense, 1983.

20

Ao utilizar-me do conceito de religiões de entidades e de divindades procurei rejeitar as formas convencionais de explicar as religiões em que ocorre o fenômeno da possessão a partir de uma suposta africanidade, ou mesmo da forte influência do modelo nagô para todas as religiões praticadas no âmbito de um terreiro. Assim, procuro não utilizar termos que considero inapropriados, a exemplo de religiões de matriz africana, religiões afrodescendentes, religiões afro-brasileiras ou simplesmente religiões negras. Ao utilizar o conceito de religiões de divindades, estou me referindo a todas as religiões em que a possessão é feita por uma divindade, que tanto pode ser um orixá ou um vodu. Quando me refiro às entidades, estou tratando de religiões em que os encantados são os que fazem a possessão. A umbanda, em alguns casos, pode ser considerada tanto como uma religião de entidades como de divindades. No tocante a questão do conceito de "Matriz africana", há que se levar em conta a dificuldade de se afirmar a existência de uma homogeneidade de qualquer aspecto cultural oriundo do continente africano, e que te- 
alguns estudiosos e pesquisadores, em uma perspectiva inaugurada por Nina Rodrigues, que expôs um dos muitos tipos de terreiros existentes em Salvador como "a forma correta" de se fazer candomblée ${ }^{1}$. Esta construção teórica foi seguida de perto por Arthur Ramos, Edison Carneiro, Roger Bastide, Ruth Landes e outros ilustres estudiosos que optaram por dar visibilidade aos terreiros vinculados ao modelo nagô baiano, preterindo as outras formas de religião e dando as mesmas o caráter de "misturadas", impuras ou simplesmente descaracterizadas ${ }^{22}$.

Os praticantes destas religiões sabem ler, e os livros que foram produzidos no contexto acadêmico foram devidamente utilizados a favor deste ou daquele terreiro, enquadrado no "modelo correto", questão que não deve e não pode ser deixada de lado por nenhum intelectual quando da análise destes fenômenos. Afirmar que esta ou aquela religião é mais "pura" ou "menos misturada" é remeter-se a juízos de valor que nem sempre

nha mantido uma "essência" na diáspora. A imensa diversidade existente no continente africano não me permite acreditar na existência de uma matriz que tenha propiciado práticas e costumes culturais desprovidos da diversidade presentes em seu local "de origem".

21 Tal exposição, a meu ver, deve ser relativizada, uma vez que Nina Rodrigues utilizou-se de uma descrição em um dado terreiro, na obra Animismo fetichista dos negros baianos, para explicar determinadas questões de suas pesquisas. A partir desta obra, no entanto, diferentes autores irão constituir e definir as linhas do terreiro descrito por Nina Rodrigues como forma correta de se cultuar os orixás em nosso país. Sobre esta questão, ver: MOTTA, Roberto. Antropologia, pensamento, dominação e sincretismo. In: BRANDÃO, Sylvana. (Org.). História das religiões no Brasil, v. 3. Recife: Ed. UFPE, 2004, p. 487-523; MOTTA, Roberto. A invenção da África: Roger Bastide, Edison Carneiro e os conceitos de memória coletiva e pureza nagô. In: LIMA, Tânia. (Org.). Sincretismo religioso - o ritual afro. Anais do IV Congresso Afro-Brasileiro. Recife: Massangana/Fundaj, 1996, v. 4, p. 2432. Para conferir a obra de Nina Rodrigues acima referida, ver: RODRIGUES, Nina. $O$ animismo fetichista dos negros baianos. Rio de Janeiro: Civ. Brasileira, 1935.

BASTIDE, Roger. As religiões africanas no Brasil - contribuição a uma sociologia das interpenetrações das civilizações. São Paulo: Pioneira/USP, 1971; BASTIDE, Roger. Estudos afro-brasileiros. São Paulo: Perspectiva, 1973; BASTIDE, Roger. Imagens do Nordeste místico em branco e preto. Rio de Janeiro: O Cruzeiro, 1945; BASTIDE, Roger. O candomblé da Bahia. São Paulo: Cia. das Letras, 2001; RAMOS, Arthur. As culturas negras no novo mundo. 4. ed. São Paulo: Cia. Ed. Nacional, 1979; RAMOS, Arthur. O folk-lore negro do Brasil - demopsychologia e psycanálise. Rio de Janeiro: Civ. Brasileira, 1935; RAMOS, Arthur. O negro brasileiro. Recife: Fundaj/Massangana, 1988 [1934]; LANDES, Ruth. A cidade das mulheres. Rio de Janeiro: Civ. Brasileira, 1967; CARNEIRO, Edison. Candomblés da Bahia. São Paulo: Martins Fontes, 2008; CARNEIRO, Edison. Negros Bantus. Rio de Janeiro: Civ. Brasileira, 1937; CARNEIRO, Edison. Os cultos de origem africana no Brasil. Rio Janeiro: Ministério da Educação e Cultura, 1959. Série Decimália.

138 Número temático: Literatura, cultura e memória negra. A Cor das Letras - UEFS, n. 12, 2011 
ajudam os estudiosos a entender o fenômeno religioso. Para tal questão, outro aspecto deve ser também colocado. A ideia de que determinadas religiões estão eivadas de maior grau de pureza, quando comparada a outras deve ser visto como um dos muitos frutos do conceito de "sincretismo", ainda hoje utilizado por grande parte dos estudiosos das religiões praticadas no terreiro. É possível afirmar que exista alguma religião que não seja dotada do fenômeno da sincretização? Ou, para melhor dizer, é possível afirmar que exista alguma religião que não tenha trazido em seu seio aspectos de outras religiões que lhe antecederam? E para além disso, não seria a atribuição da ideia de sincretismo para as religiões de terreiro uma forma de diminuí-las, quando comparadas com as religiões monoteístas, especialmente o cristianismo?

Em relação ao candomblé, considerado "mais puro" por parte de alguns renomados estudiosos, mesmo este é dotado, segundo Stefania Capone, do princípio da evolução espiritual ${ }^{23}$. Tal questão foi percebida pela autora referida em algumas casas de candomblé baianas consideradas "mais puras". A meu ver, tal observação reflete o fato de que nós vivemos em uma sociedade bastante marcada pelo cristianismo, e não é estranho que mesmo os não-cristãos sofram sua influência. $O$ diálogo religioso, feito no quotidiano, é questão suficiente para explicar os empréstimos e as trocas que são feitas tanto pelos terreiros, como pelas religiões de modo geral. Estas religiões, sejam candomblés ou outras modalidades assemelhadas, não podem e não devem ser entendidas pelo olhar e paradigma comprometido com as teses da antropologia evolucionista. Roger Bastide cometeu grave equivoco ao referir-se a estas religiões como "ilhas de África" na sociedade brasileira, uma vez que sua metáfora expõe uma visão de um terreiro distante e ao mesmo tempo isolado da sociedade em que está inserido ${ }^{24}$. Os terreiros trazem consigo heranças das diversas populações do continente africano, mas também possuem elementos de outros povos, além de um tenso diálogo com o presente, e aqui sugiro que se comece a enxergar que a dinâmica e as transformações são questões presentes nestas religiões. As religiões dos orixás, dos voduns, das entidades e as umbandas estão a todo tempo incorporando novas idéias, práticas e inovações, mesmo que estas

23 CAPONE, Stefania. A busca da África no candomblé. Tradição e poder no Brasil. Rio de Janeiro: Pallas/Contracapa, 2004.

24 BASTIDE, Roger. As religiões africanas no Brasil - contribuição a uma sociologia das interpenetrações das civilizações. Op. cit. 
sejam encobertas pelo "manto da tradição", influente discurso de legitimidade e poder.

É neste sentido que tento caminhar, no que pese as dificuldades que surgem pelo meio do caminho. Tais conceitos como afro-brasileiro, afrodescendente ou matriz africana não apontam os caminhos para um melhor entendimento das religiões de divindades e de entidades, tampouco servem como facilitadores para a descoberta de suas complexidades. Corro o risco de ser mal interpretado por aqueles que não se preocupam com a construção de uma história baseada em conceitos. Seguramente há quem acuse os historiadores de pouco refletirem sobre os mesmos, mas ainda assim creio ser extremamente importante a discussão encetada por Paul Veyne, ao afirmar que a história se escreve a partir dos conceitos ${ }^{25}$. Os historiadores e as historiadoras, assim como os estudiosos em geral precisam, com urgência, refletir sobre o uso dos conceitos em seus trabalhos e pesquisas, de modo que tenhamos ganhos diversos.

Assim sendo, gostaria de reafirmar que os conceitos precisam ser pensados em sua historicidade. Necessitamos observar os contextos históricos em que são usados, para percebermos que carregam uma diversidade de sentidos que são historicamente construídos. É nesse sentido que penso conceitos como afro-descendente, afro-brasileiro e matriz africana.

\section{REFLEXÕES SOBRE A LEI 10639 E A HISTÓRIA DA ÁFRICA}

Há duas questões a serem observadas em relação à história da África e da lei 10639. A primeira diz respeito à certa insistência em "confundir" a história dos negros brasileiros e das negras brasileiras com o continente africano, como se tal aspecto constituísse uma continuidade, ou mera relação linear. Como se todo homem negro ou mulher negra fosse, invariavelmente herdeiro natural do continente africano em alusão a cor de sua pele. Como se as vidas das pessoas não fossem objeto de construções e reconstruções diversas, dotadas de infinitas possibilidades. A relação de afeto ou de ancestralidade com o continente africano não pode ser tomado pelo aspecto natural ou biológico, questão em que, a meu ver, subjaz uma fina e sutil forma de naturalizar uma história que é feita de escolhas e recusas. Esta questão merece maior reflexão, uma vez que toda a humanidade, no

25 VEYNE, Paul. A história conceitual. In: LE GOFF, Jacques; NORA, Pierre. História: novos problemas. Rio de Janeiro: Francisco Alves, 1976, p. 64-88.

140 Número temático: Literatura, cultura e memória negra. A Cor das Letras - UEFS, n. 12, 2011 
final das contas, é oriunda deste continente, segundo os trabalhos apoiados nos achados arqueológicos mais recentes.

A segunda questão, diretamente relacionada com a primeira, diz respeito ao fato de que a lei 10639 contribui, devido ao seu texto, para que persista a idéia de que a história do continente africano possui liames diretos com a história dos negros e negras aqui estabelecidos ou nascidos há muitas gerações. Evidente que podemos encontrar indícios diversos nas práticas e costumes culturais dos negros e negras brasileiras, a exemplo de aspectos das culturas banto, iorubana e daomeana nos maracatus nação, afoxés, bem como nas religiões de divindades, os já famosos orixás e vodus (candomblé, xangô, batuque, tambor de mina). Evidente que também é possível encontrar relações entre as muitas experiências históricas dos negros e negras brasileiros com várias práticas e costumes culturais dos povos do continente africano, a exemplo dos quilombos brasileiros ou de outros modelos existentes nas Américas, mas isso não nos permite afirmar que o estudo da história do continente africano deva ser feito a partir da análise destas experiências históricas, ou mesmo das práticas e costumes culturais ou das religiões de divindades. Há que se pensar nos motivos deste amálgama que produzem equívocos e ao mesmo tempo estranhas associações entre a história de homens e mulheres nascidos em um país distante, de outras terras, mas que são ou foram insistentemente representados como africanos.

No que tange a lei 10639, possivelmente a mesma foi concebida dentro de um paradigma em que "negros" e "africanos" estão visceralmente associados. Trata-se de mais uma construção eivada de pressupostos do pan-africanismo, que faz com que todos os negros sejam parte da África, e esta um todo homogêneo ${ }^{26}$. Esta lei foi formulada sob esta influência, o que

26 Sobre o pan-africanismo, ver: KODJO, Edem; CHANAIWA, David. Pan africanismo e libertação. In: MAZRUI, Ali A; WONDJI, C. (Coord.). História geral da África, v. VIII - África desde 1935. Brasília: UNESCO/MEC, 2010, p. 897-924; HERNANDEZ, Leila Leite. A África na sala de aula. Visita à história contemporânea. São Paulo: Selo Negro, 2005; APPIAH, Kwame Anthony. Na casa de meu pai. Op. cit.; A África na filosofia da cultura. Op. cit.; ASANTE, S. K. B; CHANAIWA, David. O pan-africanismo e a integração regional. In: MAZRUI, Ali A; WONDJI, C. (Coord.). História geral da África, v. VIII - África desde 1935. Brasília: UNESCO/MEC, 2010, p. 872-896; DECRAENE, Philipe. O pan-africanismo. São Paulo: Difusão Européia do Livro, 1962; RALSTON, Richard David; MOURÃO, Fernando Augusto de Albuquerque. A África e o Novo Mundo. In: BOAHEN, Albert Adu. (Coord.). História geral da África, v. VII - África sob dominação colonial, 1880-1935. Brasília: UNESCO/MEC, 2010, p. 875-918. 
não me permite negar as intenções de seus formuladores em fazer com que os brasileiros e as brasileiras tivessem amplo conhecimento, a partir do ensino nas escolas, da história do continente africano e dos negros e negras do país. O problema reside exatamente nessa associação, que coloca em um só contexto, questões como as lutas dos escravos contra a escravidão, o racismo contemporâneo, as práticas e os costumes culturais dos negros e negras, bem como a história do continente africano e toda a sua imensa complexidade, dentre outros aspectos e questões.

A lei 10639 possui em seu âmago, de modo subjacente, elementos que corroboram para esta associação, levando-me a afirmar a urgente necessidade de se discutir os limites, as fronteiras entre definitivamente o que se trata de história do Brasil, das suas culturas e religiões, e o que é História da África. Creio que se deve deixar bem estabelecido que a história do candomblé ou do maracatu, não constitui o ensino da história da África, assim como esta não deve e não pode ser vista como um sinônimo da escravidão. Antes de esboçar as considerações finais, creio que uma análise mais aprofundada do texto da lei 19639 deva ser feita agora.

\section{SOBRE A LEI 10639: RESSONÂNCIAS DO PAN-AFRICANISMO}

Artigo 26 - Nos estabelecimentos de ensino fundamental e médio, oficiais e particulares, torna-se obrigatório o ensino sobre história e cultura afrobrasileira.

Este artigo mostra a existência da confusão entre dois campos de estudo, que a meu ver são radicalmente distintos. O que o texto da lei define como "cultura afro-brasileira" refere-se às manifestações, práticas, costumes e hábitos construídos na "diáspora", mais precisamente no Brasil, e que são fruto da composição entre aspectos diversos oriundos do continente africano, e do Brasil. Afro-brasileiro, nesse sentido, é tudo o que reúne contribuições do continente africano, trazido para o Brasil, ressignificado em contexto diferente do existente no continente africano, e acrescido de elementos diversos, sejam europeus, indígenas ou de outros povos que tomaram parte na construção deste país.

A história deste processo, qual seja, a da composição das práticas e costumes do continente africano, dos povos indígenas e outros, pode ser denominado, portanto, de afro-brasileiro. Este caminho implica, inelutavelmente, nas invisiblizações de tudo o que não é "africano". Torna-se imprescindível, no entanto, definir os limites entre o que é, na perspectiva da lei 10639, "afro-brasileiro" e "africano". Ambos os conceitos não são sinô- 
nimos e não podem ser tratados como se inexistissem diferenças entre o que é próprio da história da África, e do que saiu deste continente e que foi parar em outras terras para ser ressignificado ou objeto de composições com outras práticas.

Ocorre aqui, nesse sentido, o primeiro problema a ser estabelecido. O conceito "afro-brasileiro" não é suficiente para definir um sem número de práticas, costumes e manifestações culturais que possuem heranças diversas, a exemplo de algumas religiões como a jurema sagrada, que me referi acima, eivada de elementos indígenas e europeus, o que a torna, portanto, uma religião que está além da idéia de junção entre elementos "africanos" e brasileiros.

Para a questão racial, no que diz respeito às definições para aqueles e aquelas que possuem algum tipo de ascendência dos povos oriundos do continente africano, os conceitos "afro-brasileiro", "afro-descendente" e "africano" também não servem como referências para nomear indivíduos nascidos neste país. Ressalte-se que estou me referindo a brasileiros e brasileiras que ainda hoje possuem a cidadania plena negada pelo Estado brasileiro, apesar da aprovação de políticas públicas diversas nos últimos anos, a exemplo da própria lei 10639.

Inciso 10 $O$ conteúdo programático a que se refere o caput deste artigo incluirá o estudo da História da África e dos africanos, a luta dos negros no Brasil, a cultura negra brasileira e o negro na formação da sociedade nacional, resgatando a contribuição do povo negro nas áreas social, econômica e política pertinentes à História do Brasil [Grifo meu].

Neste trecho da lei percebem-se algumas indicações importantes, que precisam ser mais bem discutidas, para que sejam entendidos parte dos motivos existentes na confusão reinante pelo país afora entre o ensino da história da África e da cultura "afro-brasileira". Importante perceber que, se no artigo 26 , acima referido, ocorre a confusão entre ambos os aspectos, uma vez que só há a afirmação do que é tornado obrigatório, ou seja, o ensino sobre história e cultura afro-brasileira, o inciso 10 estabelece que o conteúdo programático desta matéria deverá contemplar a história da África e dos africanos, a luta dos negros no Brasil, a cultura negra brasileira e o negro na formação da sociedade nacional. Este inciso, portanto, define e estabelece as diferenças daquilo que foi tornado obrigatório. Entretanto, o inciso 2을 desconstrói as diferenças estabelecidas no inciso 1ํ, e volta a indicar o caminho de que história da África e cultura "afrobrasileira" são sinônimos, ou parte da mesma coisa. O texto do inciso 2 o 
servirá para ilustrar o que afirmo, em relação à idéia da confusão entre a história da África e da cultura "afro-brasileira":

Inciso 2o Os conteúdos referentes à história e cultura afro-brasileira, serão ministrados no âmbito de todo o currículo escolar, em especial nas áreas de Educação Artística e literatura e História brasileiras [grifo me].

Eis então, os principais motivos que justificam a existência de quantidade significativa de cursos de especialização, artigos, textos e livros em que tais temáticas são apresentadas como "mesma coisa". Há também os livros que essencializam a relação entre a cultura "afro-brasileira" e o continente africano, mostrando a existência de filiações entre um e outro, numa perspectiva linear, a exemplo da obra História e cultura afro-brasileira ${ }^{27}$. Este livro, no que pesem seus aspectos positivos, é um dos melhores exemplos para mostrar os contornos de uma relação essencializada entre a história da África e da cultura negra brasileira, uma vez que a estrutura dos capítulos do livro referido tem, em sua primeira parte, a história do continente africano, seguida de uma segunda parte em que são contemplados os conteúdos referentes à escravidão, para no fim, serem apresentados assuntos da cultura "afro-brasileira", a exemplo da história dos maracatus, candomblés e etc. Uma simples leitura do índice, que revela a forma como os capítulos do livro foram estruturados, denuncia que a autora, de forma inconsciente ou consciente, esboçou um caminho linear de que para entender a história dos negros no Brasil é preciso remontar à história da África, para em seguida percorrer os caminhos do tráfico Atlântico, para por fim, chegar às práticas e costumes culturais dos negros e negras do tempo presente.

O leitor desavisado, sem o costume da leitura de obras especificas que tratem de aspectos voltados para as religiões de divindades e de entidades, bem como da cultura negra em geral, sentirá de imediato a impressão de que tais questões podem ser entendidas como meras transposições do continente africano para o Brasil, uma vez que o livro optou por um percurso que é recorrente tanto na academia, como em algumas obras de divulgação para o grande público. Refiro-me, neste aspecto, a idéia de que religiões como o candomblé, e manifestações culturais como o maracatu são invenções do continente africano, e para o Brasil foram trazidas durante a época da escravidão. O agravante desta questão esta no fato de que tal

27 MATTOS, Regiane Augusto de. História e cultura afro-brasileira. São Paulo: Contexto, 2007.

144 Número temático: Literatura, cultura e memória negra. A Cor das Letras - UEFS, n. 12, 2011 
concepção não se encontra isolada em uma ou duas obras, mas em significativo número de livros sobre a questão.

Outro exemplo bastante evidente nesse sentido está no livro "História da África e afro-brasileira", que tem como subtítulo a frase "Em busca de nossas origens" ${ }^{28}$. Nada é mais esclarecedor, a meu ver, do que este subtítulo, que mostra a força de uma idéia que permeia quantidade significativa de títulos. Nessa concepção, a suposta origem das práticas e costumes "afro-brasileiros" está na África. Foi deste continente, nessa perspectiva, que vieram o maracatu, as congadas, o candomblé e um sem número de práticas, costumes e manifestações culturais.

Retornando a esta breve análise do inciso 10 da lei 10639, gostaria de discorrer rapidamente a respeito da existência de certa influência do panafricanismo, sobretudo quando remete os negros e negras deste país para uma categoria bastante complexa, que é a de "povo negro". Não vejo razões em estabelecer a categoria de povo para os homens negros e as muIheres negras, posto que tal questão, longe de contribuir com o fim ao preconceito e a discriminação racial, trará mais problemas, sobretudo ao indicar a existência de separações que necessitam ser destruídas, em nome de uma real igualdade racial que ainda está por ser construída neste país. Reconhecer as diferenças não significa apartar, separar. Os negros e negras devem ser vistos como parte deste país, que se constituiu a partir da junção do contraditório, das violências e agressões, presente na tomada das terras dos indígenas, trabalho forçado dos escravos, dentre outras questões. Mas este é o país dos brasileiros, que se constitui em um só povo, apesar das inúmeras contradições existentes nesta sociedade.

Outra questão que aumenta a complexidade da afirmação existente no inciso 10 , diz respeito a uma tendência explícita para a homogeneização de uma considerável diversidade de tipos humanos, com diferentes gradações do tom da pele, tipos de cabelo e traços físicos. Ao que me parece, é evidente a influência do pan-africanismo neste trecho da lei, uma vez que para os pan-africanistas os negros e negras da diáspora eram parte de um só povo, arrancados do continente africano e jogados em terras distantes para serem submetidos ao trabalho escravo. Foi no bojo do pan-africanismo que diversos intelectuais da diáspora incentivaram o "retorno" de homens

28 MELO, Elisabete; BRAGA, Luciano. História da África e afro-brasileira. Em busca de nossas origens. São Paulo: Selo Negro, 2010. 
e mulheres para o continente africano, em especial Libéria, Serra Leoa e Etiópia $^{29}$.

Creio que uma história do pan-africanismo ainda está por ser escrita, sobretudo as questões relacionadas com os movimentos de retorno ao continente africano, mas tal questão não me impede de estabelecer uma discussão crítica sobre a relação entre o pan-africanismo, setores do movimento negro brasileiro e o texto da lei 10639.

\section{CONCLUSÕES: REPENSAR OS CONCEITOS!}

Creio que após a exposição destas linhas a respeito dos conceitos já referidos ao longo do texto, bem como a breve análise da lei 10639, não posso deixar de esboçar meu profundo otimismo em relação à nova leva de trabalhos que estão sendo gestados tanto sobre a cultura negra, como sobre as religiões de divindades e de entidades, assim como da própria história da África. E neste sentido não se devem desconsiderar os aspectos positivos existentes na lei 10639, a começar pelo aumento do interesse das editoras em obras que tragam estes assuntos como foco. Também não posso deixar de lado a constatação de que se antes de 2003 os estudos voltados para a história do continente africano estavam confinadas em algumas poucas instituições sérias de ensino superior da região sudeste, agora já há um número significativo de estudiosos que se debruçam de forma específica sobre esta área em praticamente todo o país, constituindo um campo entre os historiadores brasileiros. Eu mesmo, por exemplo, sou um dos reflexos desta lei, posto que minha "virada" para os estudos da história da África se deu sob o bojo da lei 10639.

A análise dos conceitos, a crítica para a ideia de que os negros e os africanos são sinônimos, assim como a reflexão em torno da lei 10639 não devem ser entendidas como exercícios proibidos ou tabus. Precisam ser feitas, de modo que garantam um melhor entendimento destas questões, permitindo novos olhares e dimensões para objetos que há muito necessitam ser compreendidos a luz das novas teorias e abordagens da História e das ciências sociais como um todo.

29 SOUZA, Mônica Lima e. Entre as margens: o retorno à África de libertos no Brasil (18301870). Tese (Doutorado em História). Niterói, UFF, 2008; HARRIS, Joseph E; ZEGHIDOUR, Slimane. A África e a diáspora negra. In: MAZRUI, Ali A; WONDJI, C. (Coord.). História geral da África, v. VIII - África desde 1935. Brasília: UNESCO/MEC, 2010, p. 849-871.

146 Número temático: Literatura, cultura e memória negra. A Cor das Letras - UEFS, n. 12, 2011 


\section{REFERÊNCIAS}

AJAYI, J. F. Ade. (Org.). História geral da África, v. VI - África do século XIX à década de 1880. Brasília: UNESCO/MEC, 2010.

APPIAH, Kwame Anthony. Na casa de meu pai. A África na filosofia da cultura. Rio de Janeiro: Contraponto, 2008.

ASANTE, S. K. B; CHANAIWA, David. O pan-africanismo e a integração regional. In: MAZRUI, Ali A; WONDJI, C. (Coord.). História geral da África, v. VIII - África desde 1935. Brasília: UNESCO/MEC, 2010, p. 872-896.

ASSUNÇÃO, Luiz. O reino dos mestres - a tradição da jurema na umbanda nordestina. Rio de Janeiro: Pallas, 2006.

BASTIDE, Roger. As religiões africanas no Brasil - contribuição a uma sociologia das interpenetrações das civilizações. São Paulo: Pioneira/USP, 1971.

BASTIDE, Roger. Estudos afro-brasileiros. São Paulo: Perspectiva, 1973.

BASTIDE, Roger. Imagens do nordeste místico em branco e preto. Rio de Janeiro: O Cruzeiro, 1945.

BASTIDE, Roger. O candomblé da Bahia. São Paulo: Cia. das Letras, 2001.

BIRMAN, Patrícia. O que é Umbanda? São Paulo: Brasiliense, 1983.

BOAHEN, Albert Adu. (Org.). História geral da África, v. VII - África sob dominação colonial, 1880-1935. Brasília: UNESCO/MEC, 2010.

BRANDÃO, Maria do Carmo e RIOS, Luis Felipe. O catimbó-jurema do Recife. In: PRANDI, Reginaldo. (Org.). Encantaria brasileira. Rio de Janeiro: Pallas, 2001, p. 160-181.

BRANDÃO, Maria do Carmo Tinôco; NASCIMENTO, Luis Felipe Rios do. Nuevos modelos religiosos afro-recifenses y las políticas de identidad e integración. In: Antropologia en CastiIla y León e IberoAmérica, V. Emigración e integración cultural. Salamanca: Ediciones Universidad Salamanca, Instituto de Investigaciones Antropológicas de Castilla y León, s/d, p. 327338.

CAMPOS, Zuleica Dantas Pereira. O combate ao catimbó: práticas repressivas as religiões afro-umbandistas nos anos trinta e quarenta. Tese (Doutorado em História). Recife, Universidade Federal de Pernambuco, 2001.

CAPELLI, Rogério. Saindo da rota. Uma discussão sobre a pureza na religiosidade afrobrasileira. Dissertação (Mestrado em História). Niterói, Universidade Federal Fluminense, 2007.

CAPONE, Stefania. A busca da África no candomblé. Tradição e poder no Brasil. Rio de Janeiro: Pallas/Contracapa, 2004.

CARNEIRO, Edison. Candomblés da Bahia. São Paulo: Martins Fontes, 2008.

CARNEIRO, Edison. Negros Bantus. Rio de Janeiro: Civ. Brasileira, 1937.

CARNEIRO, Edison. Os cultos de origem africana no Brasil. Rio Janeiro: Ministério da Educação e Cultura, 1959. Série Decimália.

CARVALHO, José Jorge. A tradição mística afro-brasileira. Série Antropologia. Brasília: UNB, 1998. 
CASCUDO, Luis da Câmara. Meleagro - pesquisa do catimbó e notas da magia branca no Brasil. 2. ed. Rio de Janeiro: Livraria Agir Editora, 1978.

CASCUDO, Luis da Câmara. Notas sobre o catimbó. In: Idem. Novos Estudos Afro-Brasileiros. Recife: Ed. Massangana, 1988. Edição Fac-similar de Novos Estudos Afro-Brasileiros, TrabaIhos apresentados ao I Congresso Afro-brasileiro do Recife, segundo tomo. Rio de Janeiro: Civilização Brasileira, 1937;

COMAS, Juan; LITTLE, Kenneth I; SHAPIRO, Harry; LEIRIS, Michel; LÉVI-STRAUSS, Claude. Raça e ciência. São Paulo: Perspectiva, 1970.

DANTAS, Beatriz Góis. Vovó Nagô e papai branco usos e abusos da África no Brasil. Rio de Janeiro: Graal, 1988.

DECRAENE, Philipe. O pan-africanismo. São Paulo: Difusão Européia do Livro, 1962.

FERRETI, Sérgio Figueiredo. Repensando o sincretismo. São Paulo/São Luís: Edusp/Fapema, 1995.

FREYRE, Gilberto. Casa grande e senzala. São Paulo: Global, 2006.

FRY, Peter. A persistência da raça. Ensaios antropológicos sobre o Brasil e a África austral. Rio de Janeiro: Civ. Brasileira, 2005.

GOMES, Nilma Lino. Sem perder a raiz. Corpo e cabelo como símbolos da identidade negra. Belo Horizonte: Autêntica, 2006.

GUIMARÃES, Antonio Sérgio Alfredo. Classes, raças e democracia. São Paulo: Ed. 34, 2002.

GUIMARÃES, Antonio Sérgio Alfredo. Preconceito e discriminação - queixas de ofensas e tratamento desigual dos negros no Brasil. 2. ed. São Paulo: Ed. 34, 2004.

GUIMARÃES, Antonio Sérgio Alfredo. Preconceito racial. Modos, temas e tempos. São Paulo: Cortez, 2008.

GUIMARÃES, Antonio Sérgio Alfredo. Racismo e anti-racismo no Brasil. 2. ed. São Paulo: Ed. 34, 2005.

GUIMARÃES, Antonio Sérgio Alfredo; HUNTLEY, Lynn. Tirando a máscara. Ensaios sobre o racismo no Brasil. São Paulo: Paz e Terra, 2000.

HARRIS, Joseph E; ZEGHIDOUR, Slimane. A África e a diáspora negra. In: MAZRUI, Ali A; WONDJI, C. (Coord.). História geral da África, v. VIII - África desde 1935. Brasília: UNESCO/MEC, 2010, p. 849-871.

HASENBALG, Carlos A.; MUNANGA, Kabenguele; SCHWARCZ, Lília Moritz. (Org.). Racismo: perspectivas para um estudo contextualizado da sociedade brasileira. Niterói: EDUFF, 1998.

HASENBALG, Carlos. Discriminação e desigualdades raciais no Brasil. Belo Horizonte: Ed. UFMG; Rio de Janeiro, IUPERJ, 2005.

HERNANDEZ, Leila Leite. A África na sala de aula. Visita à história contemporânea. São Paulo: Selo Negro, 2005.

KI-ZERBO, Joseph. História da África negra, v. I. Mem Martins (Portugal): Biblioteca Universitária, 2002.

KODJO, Edem; CHANAIWA, David. Pan africanismo e libertação. In: MAZRUI, Ali A; WONDJI, C. (Coord.). História geral da África, v. VIII - África desde 1935. Brasília: UNESCO/MEC, 2010, p. 897-924.

148 Número temático: Literatura, cultura e memória negra. A Cor das Letras - UEFS, n. 12, 2011 
KOSELLECK, Reinhart. Futuro passado. Rio de Janeiro: Contraponto, 2006.

LANDES, Ruth. A cidade das mulheres. Rio de Janeiro: Civ. Brasileira, 1967.

LIMA, Ivaldo Marciano de França. Uma religião que cura, consola e diverte - as redes de sociabilidade da Jurema sagrada. Cadernos de Estudos Sociais, v. 20, n. 2, jul.-dez. 2004.

LOVEJOY, Paul. E. A escravidão na África. Uma história de suas transformações. Rio de Janeiro: Civ. Brasileira, 2002.

LOVEJOY, Paul. Identidade e a miragem da etnicidade. A jornada de Mahommah Gardo Baquaqua para as Américas. Afro-Ásia, n. 27, p. 9-39, 2002.

LUZURIAGA, José Martin Desmaras. Jurema e cura - ensaio etnográfico sobre uma forma de jurema nas periferias do Recife. Dissertação (Mestrado em Antropologia). Recife, Universidade Federal de Pernambuco, 2001.

M’BOKOLO, Elikia. África negra. História e civilizações - Tomo I (até o século XVIII). Salvador/São Paulo: EDUFBA/Casa das Áfricas, 2009.

MATTOS, Regiane Augusto de. História e cultura afro-brasileira. São Paulo: Contexto, 2007.

MBEMBE, Achille. As formas africanas de auto-inscrição. Estudos Afro-Asiáticos, n. 1, 2001, p. 172-209.

MELO, Elisabete; BRAGA, Luciano. História da África e afro-brasileira. Em busca de nossas origens. São Paulo: Selo Negro, 2010.

MEYER, Marlyse. Maria Padilha e toda a sua quadrilha - de amante de um rei de Castela a Pomba-Gira de umbanda. São Paulo: Duas Cidades, 1993.

MOTTA, Roberto Mauro Cortez. Jurema. In: MAIOR, Mário Souto; VALENTE, Waldemar. (Org.). Antologia Pernambucana de folclore. Recife: Massangana, 1988, p. 267-268.

MOTTA, Roberto. A invenção da África: Roger Bastide, Edison Carneiro e os conceitos de memória coletiva e pureza nagô. In: LIMA, Tânia. (Org.). Sincretismo religioso - o ritual afro. Anais do IV Congresso Afro-Brasileiro. Recife: Massangana/Fundaj, 1996, v. 4, p. 24-32.

MOTTA, Roberto. Antropologia, pensamento, dominação e sincretismo. In: BRANDÃO, Sylvana. (Org.). História das religiões no Brasil, v. 3, Recife: Ed. da UFPE, 2004, p. 487-523.

MOTTA, Roberto. Catimbós, xangôs e umbandas na região do Recife. In: MOTTA, Roberto. (Coord.). Os afros-brasileiros. Anais do III congresso afro-brasileiro. Recife: Massangana, 1985, p. 109-123.

MOTTA, Roberto. Religiões afro-recifenses: ensaios de classificação. Revista Antropológicas, ano II, v. 2, Série Religiões populares, Recife: Ed. UFPE, 1997, p. 11-34.

MUNANGA, Kabengelê. Rediscutindo a mestiçagem no Brasil. Belo Horizonte: Autêntica, 2004.

NAXARA, Márcia Regina Capelari. Estrangeiro em sua própria terra. Representações do brasileiro - 1870/1920. São Paulo: Annablume/FAPESP, 2002.

NEGRÃO, Lísias. A umbanda como expressão de religiosidade popular. Religião e sociedade, Rio de Janeiro: Civ. Brasileira, 1979.

NEGRÃO, Lísias. Umbanda: entre a cruz e a encruzilhada. Tempo Social, São Paulo, v. 5, 1994. 
NEGRÃO, Lísias. Umbanda: entre a cruz e a encruzilhada: formação do campo umbandista em São Paulo. São Paulo: EDUSP, 1996.

NOGUEIRA, Oracy. Preconceito de marca. As relações raciais em Itapetininga. São Paulo: EDUSP, 1998.

OGOT, B. A. A história das sociedades africanas de 1500 a 1800: conclusão. In: OGOT, B. A. (Org.). História geral da África, v. V - África do século XVI ao XVIII. Brasília: UNESCO/MEC, 2010, p. 1057-1069.

OLIVER, Roland. A experiência africana - da pré-história aos dias atuais. Jorge Zahar, Rio de Janeiro: 1994.

ORTIZ, Renato. A morte branca do feiticeiro negro: umbanda e sociedade brasileira. 2. ed. São Paulo: Brasiliense, 1991.

PINTO, Clélia Moreira. Saravá Jurema Sagrada: as várias faces de um culto mediúnico. Dissertação (Mestrado em Antropologia). Programa de Pós Graduação em antropologia da UFPE, Recife, 1995.

QUEIROZ, Martha Rosa Figueira. Religiões afro-brasileiras no Recife: intelectuais, policiais e repressão. 1999. Dissertação (Mestrado em história). Programa de Pós-Graduação em História, Universidade Federal de Pernambuco, Recife, 1999.

RALSTON, Richard David; MOURÃO, Fernando Augusto de Albuquerque. A África e o Novo Mundo. In: BOAHEN, Albert Adu. (Coord). História geral da África, v. VII - África sob dominação colonial, 1880-1935. Brasília: UNESCO/MEC, 2010, p. 875-918.

RAMOS, Arthur. As culturas negras no novo mundo. 4. ed. São Paulo: Cia. Ed. Nacional, 1979.

RAMOS, Arthur. O folk-lore negro do Brasil - demopsychologia e psycanálise. Rio de Janeiro: Civ. Brasileira, 1935.

RAMOS, Arthur. O negro Brasileiro. Recife: Fundaj/Massangana, 1988 [1934].

REDIKER, Marcus. O navio negreiro. Uma história humana. São Paulo: Cia. das Letras, 2011.

RODRIGUES, Nina. O animismo fetichista dos negros baianos. Rio de Janeiro: Civ. Brasileira, 1935.

SALLES, Sandro Guimarães de. À sombra da jurema: a tradição dos mestres juremeiros na umbanda de Alhandra. Anthropólogicas, ano 8, v. 15, p. 99-122, 2004.

SANTOS, Jocélio Teles. O negro no espelho: imagens e discursos nos salões de beleza étnicos. Estudos Afro-Asiáticos, n. 38, p. 49-65, 2000.

SILVA, Alberto da Costa e. Francisco Félix de Souza, mercador de escravos. Rio de Janeiro: Nova Fronteira/Ed. UERJ, 2004.

SOUZA, Mônica Lima e. Entre as margens: o retorno à África de libertos no Brasil (18301870). Tese (Doutorado em História). Universidade Federal Fluminense, Niterói, 2008.

SOUZA, Neusa Santos. Tornar-se negro. Rio de Janeiro: Graal, 1990.

THORNTON, John. A África e os africanos na formação do mundo atlântico - 1400-1800. Rio de Janeiro: Elsevier, 2004.

TURRA, Cleusa; VENTURI, Gustavo. (Org.). Racismo cordial - a mais completa análise sobre preconceito de cor no Brasil. São Paulo: Ática, 1998. 
UFPE; SALLES, Sandro Guimarães de. À sombra da jurema encantada: mestres juremeiros na umbanda de Alhandra. Recife: Ed.UFPE, 2010.

VANDEZANDE, René. Catimbó. Pesquisa exploratória sobre uma forma nordestina de religião mediúnica. Dissertação (Mestrado em Sociologia). UFPE, Recife, 1975.

VEYNE, Paul. A história conceitual. In: LE GOFF, Jacques; NORA, Pierre. História: novos problemas. Rio de Janeiro: Francisco Alves, 1976.

WESSELING, H. L. Dividir para dominar. A partilha da África 1880-1914. Rio de Janeiro: UFRJ/Revan, 1998.

WIEVIORKA, Michel. O racismo, uma introdução. São Paulo: Perspectiva, 2007. 
